Review

\title{
Stimuli-Sensitive Cell Penetrating Peptide-Modified Nanocarriers
}

\author{
Federico Perche
}

Centre de Biophysique Moléculaire, UPR CNRS 4301, Rue Charles Sadron, Orléans, 45071 CEDEX 2, France; federico.perche@cnrs-orleans.fr

Received: 6 September 2019; Accepted: 30 September 2019; Published: 11 October 2019

\begin{abstract}
The integration of drugs into nanocarriers favorably altered their pharmacodynamics and pharmacokinetics compared to free drugs, and increased their therapeutic index. However, selective cellular internalization in diseased tissues rather than normal tissues still presents a formidable challenge. In this chapter I will cover solutions involving environment-responsive cell-penetrating peptides (CPPs). I will discuss properties of CPPs as universal cellular uptake enhancers, and the modifications imparted to CPP-modified nanocarriers to confine CPP activation to diseased tissues.
\end{abstract}

Keywords: peptides; cellular uptake; responsive

\section{Introduction}

Formulation of drugs with nanocarriers increased their circulation time through decreased elimination by biological defense mechanisms, resulting in improved patient compliance and survival over free drugs against cancer [1-6]. Once the diseased tissues are reached after administration, the nanocarriers need to be internalized for the drug cargo to act on its intracellular target. One of the most frequent modification to increase intracellular drug delivery is the grafting of cell-penetrating peptides (CPPs) [7-9]. Conjugation of CPPs to increase cellular uptake stems from mimicry of viruses uptake. Indeed, among the most powerful CPPs are the transcription and transactivator from HIV-1 (TAT) and VP22 of herpes virus, both promoters of virus transduction [10,11].

CPPs are either natural or synthetic and possess cationic, amphiphatic or hydrophobic membrane translocation domains that enhanced the intracellular delivery of several types of nanocarriers [7,11-13]. However, conjugation of CPPs is a double-edged sword as their membrane translocation power is limited by the lack of CPP tropism to diseased tissues, with detrimental uptake of CPP-modified nanocarriers by normal tissues [11,14].

Exposition of CPP only after activation by pathophysiological traits has been proposed to reduce the internalization of CPP-modified nanocarriers by normal tissues [11,14]. In such environment-responsive CPP-modified nanocarriers, the CPP is hold in a stimuli-labile scabbard until being drawn out after encountering the appropriate stimuli. The principal environment stimuli used are light, acidosis, redox imbalance and proteases [11,15].

After a brief description of CPPs properties, I will discuss strategies of environment-responsive CPP-modified nanocarriers.

\section{Cell Penetrating Peptides}

Primarily, CPPs were peptides with membrane translocation properties identified in viruses (e.g., HIV TAT, herpes virus VP22), in fly (Penetratin), in bacteria (Mce1A) (Table 1) $[8,10,16,17]$. CPPs are usually classified as: biologically derived that is, the translocation domain sequence of protein sufficient for cellular membrane crossing; model CPPs which contain translocation sequences of biological CPPs together with modifications to increase their hydrophobicity or stabilize alpha helixes such as 
$\alpha$-aminobutyric acid and; synthetic CPPs which are either fusion of domains from different biological sources or have been identified by phage display $[13,18,19]$. These peptides are usually rich in basic residues and thus positively charged at the extracellular $\mathrm{pH}$ of 7.2-7.4, a positive charge resulting in electrostatic interactions with negatively charged cell surfaceleading to their rapid endocytosis $[12,20]$.

Several modes of cellular internalization of CPPs have been described (Reviewed in [8,21-23]) One can distinguish endocytic internalization and non-endocytic internalization modes of CPPs. Endocytosis appears to be the mode of entry of most CPPS [21,23,24]. However, endocytic uptake (micropinocytosis, clathrin-mediated endocytosis and caveolae-mediated endocytosis) all lead of to CPP-cargo accumulation in lysosomes [21,23,25-27]. To address endosomal accumulation dual-function CPPS 3 strategies have been used: (1) insertion of histidine residues in the CPP for protonation at acidic endosomal $\mathrm{pH}$ followed by an increase of osmotic pressure destabilizing the endosomal membrane [28], (2) introduction of $\mathrm{pH}$-sensitive domains that destabilize membranes at endosomal $\mathrm{pH}$ such as influenza hemagglutinin-derived peptide HA2 and artificially designed peptide GALA $[24,29,30], 3)$ coupling of hydrophobic peptide domains to the CPP with or without spacer [26].

On the other hand, CPPs are also able of direct membrane penetration by pore formation, thereby bypassing endosomes with direct delivery into the cytosol, with examples including TAT and Pep-1 $[8,22]$. The pore formation is induced by a change of CPP orientation followed by insertion in the membrane bilayer when the CPP coverage is dense enough at the cell surface $[25,26,31]$.

Mechanisms of cellular uptake of CPP conjugated to low molecular weight agents or grafted onto nanoparticles has been reviewed in detail elsewhere [7-9,16,32,33]. The list of identified CPPs keeps increasing and, synthetic CPPs such as octaarginine (R8) have been designed to enhance cellular uptake of CPP-conjugated materials [16,31,34].

The intracellular delivery and therapeutic activity of various cargoes such as small molecules (e.g., Doxorubicin), proteins (e.g., $\beta$-galactosidase), nucleic acids (e.g., siRNA), have been increased by conjugation to CPPs $[9,13,18,34]$. Conjugation of CPPs also increased the crossing of biological barriers such as the blood brain barrier (BBB) and the intestinal mucosa. In one example of facilitated BBB crossing, conjugation of the Rabies Virus Glycoprotein (RVG)-derived CPP to brain-derived neurotropic factor augmented its accumulation into the central nervous system after intravenous delivery [35]. Later, a synthetic CPP composed of RVG fused to nonaarginine (RVG-9R) could carry siRNA into the brain after systemic injection with, gene silencing in neurons resulting in protection against viral encephalitis [36].

Oral delivery is a very common route for pharmaceuticals and CPPs are helpful tools to increase their intestinal absorption $[4,14,34]$. Examples of CPPs capable of intestinal mucosa transduction include TAT and Penetratin [14,37].

The pharmacological interest of CPPs conjugation is validated by the increasing number of CPP-drug conjugated reaching Phase I / Phase II clinical trials for indications such as cancer, vascular diseases or, dystrophy (see [14,22] for references to clinical trials).

Since nanoparticles (NPs) have improved efficacy and flexibility in cargo loading over conjugation strategies, CPP modifications were also applied to nanocarriers $[4,6,9,18]$. Even though addition of $\mathrm{CPP}$ units to nanocarriers primarily aims at unspecifically addressing the limited endocytosis challenge of nanomedicines, I will describe stimuli-sensitive strategies able to tame the membrane transduction power of CPPs to turn them into targeting ligands [11,14,38]. 
Table 1. Examples of conventional and stimuli-sensitive cell-penetrating peptides CPPs.

\begin{tabular}{cccc}
\hline CPP Name & CPP Sequence & Stimuli & Ref. \\
\hline TP10 & AGYLLGKINLKALAALAKKIL-NH2 & & {$[39]$} \\
\hline TP10-5 & $\begin{array}{c}\text { AGYLLGKINLKKLAKL(Aib)KKIL-NH2 } \\
\text { Aib: } \alpha \text {-amino-isobutyric acid }\end{array}$ & {$[40]$} \\
\hline TH & AGYLLGHINLHHLAHL(Aib)HHIL-NH2 & Protonation at tumor pH & {$[40]$} \\
\hline Penetratin & RQIKIWFQNRRMKWKK-NH2 & & {$[39]$} \\
\hline TAT-(47-57) & YGRKKRRQRRR-NH2 & {$[39]$} \\
\hline $\begin{array}{c}\text { Rabies virus glycoprotein } \\
\text { (RVG) }\end{array}$ & $\begin{array}{c}\text { KSVRTWNEIIPSKGCLRVGGRCHPH } \\
\text { VNGGGRRRRRRR }\end{array}$ & {$[35]$} \\
\hline Polyarginine & $\mathrm{R}_{\mathrm{n} \text {, most frequently R8 }}$ & {$[18]$} \\
\hline Activatable CPP (ACPP) & $\begin{array}{c}\text { Succinyl-E8-(x)-PLGLAG-R9-C(Cy5)-NH2 } \\
\text { x = 6-aminohexanoyl }\end{array}$ & Matrix metalloproteases (MMP) 2/9 & {$[39]$} \\
\hline $\begin{array}{c}\text { Dual-triggered ACPP } \\
\text { (dtACPP) }\end{array}$ & $\begin{array}{c}\text { E4K4-aminohexanoic } \\
\text { linker-PLGLAG-R9-minohexanoic }\end{array}$ & Low pH and MMP2 & {$[41]$} \\
\hline
\end{tabular}

\subsection{Stimuli-Sensitive CPP-Modified Nanocarriers}

Although CPP conjugation greatly increased the cellular uptake of pharmaceuticals and nanocarriers in cell lines, their rapid and non-specific translocation of cell membranes is a challenge for in vivo applications $[14,42]$. Such low specificity of CPPs in vivo is evidenced by the retention of TAT and $\mathrm{R} 9$ at the injection site, with secondary distribution to the liver and, rapid blood clearance, demonstrating a requirement for improved pharmacokinetics [42,43]. To address the CPP dilemma of "potential to induce uptake by any cells but without specificity", conversion of CPPs into stimuli-sensitive CPPs whose endocytosis is triggered only when appropriate pathophysiological conditions are met have been developed $[6,14,42,44]$.

In stimuli-sensitive CPPs, the membrane translocation activity is quenched by a scabbard, scabbard which is selectively removed / degraded by factors present in the diseased tissue environment to induce cellular uptake only at the target site. Several types of scabbards are employed: either a voluminous masking group released after cleavage, a photo-responsive protective group cleaved after irradiation or, a charge-reversal unit (Figure 1). 


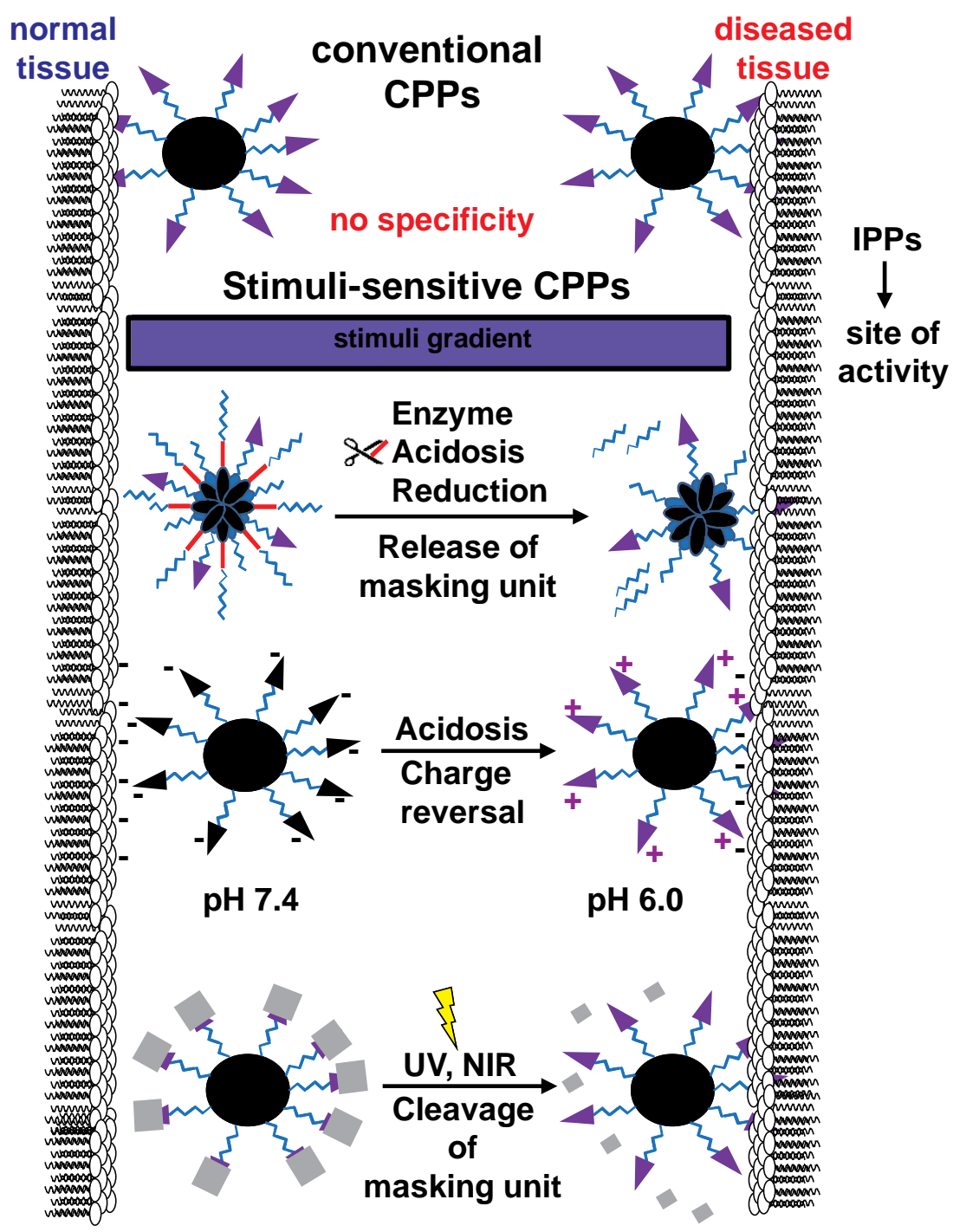

Figure 1. Strategies of CPP conjugation to nanocarriers. Conventional CPP coupling unselectively increases nanocarrier's endocytosis both by normal and diseased tissues. Oppositely, stimuli-sensitive CPPs display higher selectivity as CPPs are hold in a scabbard until activation by a threshold concentration of stimuli thereby decreasing non-specific endocytosis.

The benefit of stimuli-sensitive CPPs over conventional CPPs has been well illustrated by Tsien et al. [42]. They compared the biodistribution and pharmacokinetics of systemically-injected fluorescently-labeled CPPs and stimuli-sensitive CPPs (ACPP, Activatable CPPs). Immediately after injection, CPP bound to the first cells they encountered that is tail vein vascular cells, with a secondary distribution to liver and kidney. On the contrary, minimal binding to tail vein vasculature was observed with ACPP, resulting in longer stability in the blood circulation thereby increasing the possibility to distribute to diseased tissues.

The second strategy of stimuli-sensitive CPPs consists in steric hindrance masking of CPPs by a hydrophilic group such as a polyethyleneglycol (PEG) conjugated onto the nanocarrier by a stimuli-labile linker to keep CPPs inactive until reaching the diseased tissue $[8,9,11,15,45]$. In addition to serve as a scabbard, PEG engraftment also increases the biocompatibility of nanocarriers and takes advantage of the vast library of chemical strategies available for PEG conjugation [46,47].

Both strategies may be viewed as integration of the CPP sword to cut cell membrane for nanocarrier cellular penetration into a labile scabbard, with the pathophysiological stimuli playing the role of attack signal to advantageously combine defense against extracellular immune system and offensive 
engaging of diseased cells. I will describe strategies combining a CPP sword and scabbard where the attack signal is either light irradiation, tumor acidosis, redox imbalance, or environment proteases.

\subsection{Light-Responsive CPP-Modified Nanocarriers}

The development of two-photon lasers, light emitting diodes (LEDs), and near infrared (NIR) sources as well as optical fibers make light an attractive physical stimulus [48]. CPP-modified nanocarriers with light-triggered drawing out of CPP rely on photo-responsive linkers which are cleaved after irradiation [49].

The design of nanocarriers with light-triggered CPP display is the focus of Pr. Mei's group and, their work on photo-responsive CPPs (pCPP) will be presented to cover potential applications of this strategy. They designed di-oleyl-sn-phosphatidylethanolamine-PEG-Photoresponsive group/CPP (DSPE-PEG-pCPP) conjugates where the hydrophobicity of the DSPE allows insertion into liposomes or nanostructured lipid carriers (NLC), the PEG unit imparts biocompability and improves the ability of the CPP to interact with the cell membrane and, the photo-cleavable unit cages the CPP until irradiation.

One of the CPP photo-cleavable CPP masking group they used is UV-sensitive 6-nitroveratrylcarbonyl (Nvoc) for paclitaxel (PTX) delivery [50]. First, they conjugated UV-labile Nvoc to the Lysine side chains of a Penetratin-derived CPP (CKRRMKWKK) to obtain an Nvoc/CPP complex designed as photo-responsive CPP (pCPP). Second, pCPP was coupled to DSPE-PEG2000-maleimyde to produce DSPE-PEG2000-pCPP. Finally, DSPE-PEG2000-pCPP was used for the preparation of PTX-loaded nanostructured lipid carriers (pCPP-NLC). They confirmed UV-induced in vitro removal of the masking unit with more than $85 \%$ of Nvoc groups cleaved after 10 min irradiation $(\lambda=365 \mathrm{~nm})$. Light-induced CPP exposure increased by 2-fold the cellular uptake of PCPP-NLC over un-irradiated counterparts and, allowed deeper penetration of multicellular spheroids.

The imaging results of multicellular spheroids penetration illustrate the contribution of light-triggered CPP display to decreased non-specific interactions. Indeed, whereas CPP-modified NLC without masking group ("always on" and non-specific CPP-NLC) showed significant penetration across spheroid cell layers, non-irradiated pCPP-NLC distribution was limited to outermost spheroid cell layers and exhibited significant spheroid penetration only after UV irradiation.

Despite these promising results, the dependence on UV light irradiation is bound with limitations such as limited skin penetration at these wavelengths and photo-toxicity [51]. These limitations were addressed by changing the UV-labile Nvoc group for a near infrared (NIR)-sensitive one, 4, 5-dimethoxy-2-nitrobenzoyl [52]. A $30 \mathrm{~min}$ NIR $(\lambda=740 \mathrm{~nm})$ irradiation of these PTX-loaded NIR-responsive pCPP-NLC led to $85 \%$ CPP uncaging in vitro and increased cellular uptake by nearly 2-fold compared to un-irradiated PCPP-NLC resulting in antitumor activity in vivo after intravenous administration.

Phototoxicity is another limitation of photoreactive compounds with both direct toxicity due to photobinding of endogeneous molecules and indirect toxicity due to oxidation of proteins or DNA resulting in skin irritation and cellular apoptosis (reviewed in [48]).

\subsection{Enzyme-Responsive CPP-Modified Nanocarriers}

Growth of solid tumors requires both digestion of the dense extracellular matrix and construction of a tumor neovasculature to get nutrients and support metastasis, two calls answered by secretion of proteases such as matrix metalloproteases (MMP) and angiogenic factors by tumor cells [53]. This promoted the use of protease-substrate peptides as linkers for drug delivery, with several protease-substrate / CPP combination strategies $[15,44,54,55]$.

Torchilin and coworkers developed an enzyme-triggered TAT display for tumor-specific paclitaxel delivery using MMP2-sensitive PEG-drug conjugates (Figure 2) [19]. 


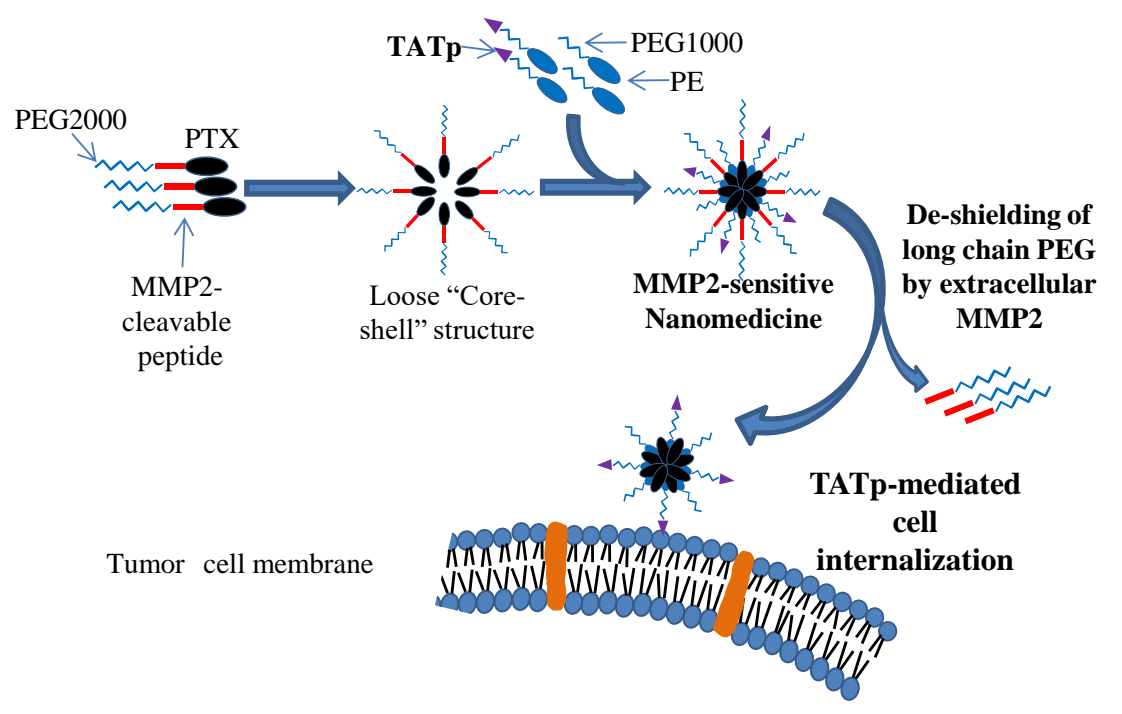

Figure 2. Drug delivery strategy of the MMP2-sensitive self-assembled PTX nanopreparation. The PEG2000-substrate peptide-PTX conjugate self-assembles into loose micelles which are stabilized by lipids harboring TAT. Whereas TAT is buried by longer PEG layers in the circulation, cleavage of the substrate by tumor-secreted MMP2 leads to TAT-mediated cellular internalization for anticancer therapy. Reproduced with permission from [19].

In this formulation, paclitaxel (PTX) is solubilized in the hydrophobic core with a high drug loading (15\% by weight), a core coated by a PEG shell of an MMP2-cleavable PEG2000-substrate peptide-PTX conjugate, a shorter DSPE-PEG1000-TAT conjugate and, PEG1000-DSPE as a colipid building block to further stabilize the assembly.

These units acted in a cooperative manner. In the circulation the PEG shield favored primary tumor accumulation by EPR effect and decreased toxicity to healthy tissues associated with free drug and burst release from micelles after intravenous injection. Once in the tumor bed, MMP2-conditioned cellular uptake resulted in superior therapeutic activity over Taxol ${ }^{\odot}$ and insensitive PTX micelles.

Tsien's group introduced a new modality of CPP activation by proteases, with nonaarginine (R9) CPP masked by an oppositely charged peptide (E8) via a peptide substrate linker [42]. The matching peptide neutralizes CPP's charge to decrease non-specific interactions, the CPP is exposed after cleavage of the peptide linker by enzymes overexpressed in the tumor microenvironment, a concept coined Activatable Cell Penetrating Peptide (ACPP, Table 1) [56]. Functionalization of ACPP with a Cy5-Cy7 FRET pair, allowed detection of primary tumors and metastases and removal of tumor tissue during image-guided surgery [57]. This strategy has also been applied to drug delivery and some examples will be detailed.

Urokinase plasminogen activator (uPA) is particularly overexpressed in glioma's neovasculature and an uPA-triggered CPP was developed for paclitaxel anti-glioma therapy [58]. The biodistribution of bare PTX-loaded NP (NP), CPP-conjugated PTX-loaded NP (CNP) and, uPA Activatable CPP-conjugated PTX-loaded NP (ANP) was compared. Whereas ANP and CNP showed similar accumulation in normal tissues -including normal brains- after intravenous injection, ANP exhibited a 2-fold higher accumulation in intracranial glioma over CNP and NP. This higher accumulation in brain tumors was mirrored with a longer survival of ANP-treated glioma-bearing mice demonstrating promising therapeutic benefits of uPA ACPP for drug delivery to brain tumors.

For an even more selective tumor-targeted DNA delivery, dendrimers conjugated with an ACPP triggered by low $\mathrm{pH}$ and secreted MMP2 (dual-triggered ACPP, dtACPP) were developed [41]. In this formulation, dtACPP (E4K4-aminohexanoic linker-PLGLAG-R9-aminohexanoic linker-MMP2 cleavable peptide) is composed of a CPP (R9) linked to a neutralizing E4K4 peptide via an MMP2-substrate peptide. The charges of arginines are electrostatistically complexed by E4K4 $(\mathrm{pKa}=6.4)$, negatively charged at $\mathrm{pH} 7.4$ but acquiring a positive charge at acidic tumor $\mathrm{pH}$. While 
the low $\mathrm{pH}$ decreases interaction between $\mathrm{R} 9$ and E4K4, the CPP still cannot interact with cells and, only becomes activated after cleavage of the linker by MMP2 assuring high tumor selectivity. After intravenous injection, EGFP encoding DNA-loaded dendrimers conjugated with dtACPP led to superior tumor accumulation / lower liver entrapment and, higher GFP expression in cancer cells over those conjugated with uncleavable ACPP and R9 only, demonstrating the benefit of this two-step controlled activation of CPP. Finally, multifunctional liposomes encapsulating siRNA were functionalized with folate and a dtACPP responsive to prostate-specific antigen (PSA) and low $\mathrm{pH}$, for further increased tumor selectivity [59]. In this platform, folate is expected to bind to prostate-membrane specific antigen (PMSA) which is enriched at the membrane of prostate cancer cells. Folate is coupled to a longer PEG conjugate (DSPE-PEG5000-Folate) than dtACPP (DSPE-PEG2000-dtACPP). Thus, folate is expected to favor the interaction of the liposomes with cancer cell membrane before activation of the R8 CPP by low $\mathrm{pH}$ and secreted PSA in the tumor microenvironment. Authors demonstrated enhanced tumor accumulation and therapeutic activity of multifunctional liposomes over these with only folate, or only dtACPP.

\subsection{Acidosis-Responsive CPP-Modified Nanocarriers}

The dependence of tumor tissues on glycolysis for ATP generation over oxidative respiration, is associatedwith overproduction of carbonic and lactic acid resulings in acidosis of tumor tissues [60]. This acid $\mathrm{pH}$ of tumors ( $\mathrm{pH}<6.8$ compared to physiological $\mathrm{pH}$ of 7.2-7.4 in normal tissues) has fueled the design of $\mathrm{pH}$-responsive linkers for both tumor drug delivery and imaging [6,15,60-62]. Thus, $\mathrm{pH}$ has been used as stimuli for tumor-targeted delivery with three frequent design options: CPP exposure after detachment of a PEG scabbard, optimization of the CPP sequence to turn it into a protonable peptide, introduction of a charge-reversal moiety.

Apte and coworkers developed doxorubicin-loaded immune-liposomes with acidosis-induced exposure of TAT for cancer therapy $[63,64]$. In their design, PEGylated liposomes encapsulating doxorubicin were coated with PEG conjugates of distinct lengths disposed as onion rings: the longest PEG conjugate carries the cancer cell surface nucleosomes-specific antibody $2 \mathrm{C} 5$ for tumor-targeted delivery (2C5-PEG3400-DSPE), the PEG conjugate of intermediate length harbors an hydrazone (Hz) bond for cleavage at acidic tumor $\mathrm{pH}$, a cleavage leading to the exposure of previously buried TAT (introduced as a TAT-PEG1000-DSPE conjugate). Acid $\mathrm{pH}$ induced TAT exposure allowed 1.8-fold higher cellular uptake of liposomes in cellulo after incubation at pH 5.0 compared to $\mathrm{pH} 7.4$ and, superior tumor accumulation and decrease in tumor growth after systemic administration over non pH-sensitive liposomes.

Another solution to $\mathrm{pH}$-sensitive CPP-mediated endocytosis of nanocarriers is to alter the sequence of the CPP replacing the positively charged amino acids by protonable ones such as histidine to convert it into a $\mathrm{pH}$-sensitive CPP.

I will describe the steps of transportan 10 (TP10) optimization to illustrate this CPP design strategy $[40,65,66]$. TP10 is a CPP derived from the mastoparan wasp peptide, a lysine rich $\alpha$ helical peptide, with a high proportion of positively charged residues that favor the intracellular delivery of conjugated therapeutic cargo [39]. It was first reported that conjugation of TP10 to DNA dramatically increased its cellular uptake, with a superior intracellular DNA delivery over penetratinand TAT-conjugated DNA [39]. However, this superior uptake was mirrored with high cell content leakage and cytotoxicity. Thus, optimization of TP10 sequence was required to turn it into a potent and safe CPP. Based on the observation that TAT and Penetratin have a higher density of positively charged residues, the first optimization step was substitution of TP10 alanine residues by lysine. TP10- 5 was identified as an improved analog of TP10. This peptide contains two alanine-to-lysine substitutions and inclusion of the alpha helix stabilizer $\alpha$-aminobutyric acid (Aib) to increase amphiphicity and facilitate cell membrane crossing. Whereas fluorescently-labeled TP10-5 displayed increased cellular uptake over TP10 both in normal and cancer cells, this increase was associated with higher cytotoxicity, suggesting the need for a second optimization step. The second step was to convert TP10-5 into a 
pH-triggered CPP for increased specificity towards cancer cells [40]. To do so, they replaced lysines in TP10 (pKa $=10.2$, positively charged at extracellular $\mathrm{pH}$ 7.2-7.4) by histidines (protonable at acidic $\mathrm{pH}$, Figure 3) to obtain the TH peptide (Table 1).

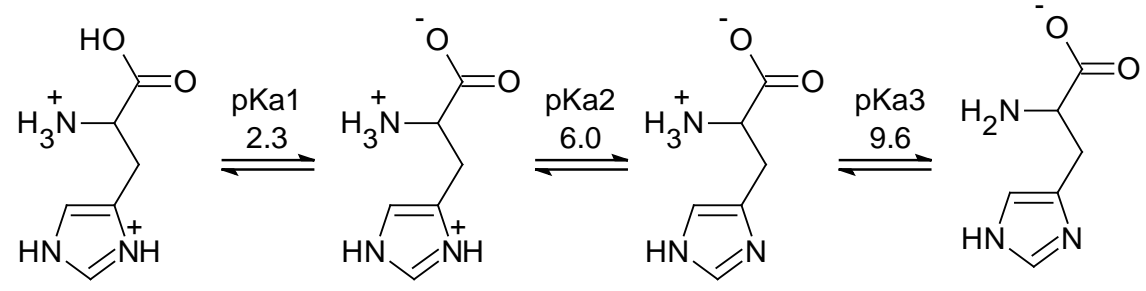

Figure 3. Histidine protonation steps.

This peptide demonstrated $\mathrm{pH}$-dependent cellular uptake with a more than 2-fold higher cell-associated fluorescence detected by flow cytometry after incubation at $\mathrm{pH} 6.0$ over $\mathrm{pH}$ 7.4. TH acidosis-conditioned cell membrane crossing also abolished the cytotoxicity of TP10 at pH 7.4 and, when conjugated to cisplatin, showed higher anticancer activity at $\mathrm{pH} 6.0$ compared to $\mathrm{pH}$ 7.4.

In the final step, paclitaxel-loaded liposomes decorated with this ideal derivative of TP10 exhibited acid $\mathrm{pH}$-dependent cellular uptake both in cancer cell monolayers and spheroids [66]. Finally, activation of TH-conjugated liposomes by tumor microenvironment was confirmed in vivo with 1.67-fold higher accumulation of TH-liposomes over non-responsive liposomes after intravenous injection. Subsequently, demonstration of superior anticancer activity of TH-conjugated paclitaxel-loaded liposomes in several tumor models expands the list of tumor-targeted CPPs [66-68].

Another example of sequence defined $\mathrm{pH}$-responsive CPP is the R6H4 CPP which has been used for gambogic acid (GA) tumor-targeted delivery [69]. GA-loaded lipid nanoparticles (cp-rHDL/GA nanoparticles) include recombinant high density lipoprotein (rHDL) to increase drug loading and R6H4 as CPP (cp) for acid pH-conditioned intracellular GA delivery. Tumor selectivity relies on $\mathrm{R} 6 \mathrm{H} 4$, a synthetic CPP which contains arginine for interaction with cell membranes and membrane translocation and, protonable histidines for acid-triggered uptake. The balance of arginine/histidine was finely tuned to achieve a 4-fold enhanced cellular uptake of $\mathrm{R} 6 \mathrm{H} 4$ at $\mathrm{pH} 6.4$ over $\mathrm{pH} 7.4$ [70]. In sharp contrast, peptides without histidines or with higher arginine-to-histidine ratios had no pH-selectivity. Cp-rHDL/GA NP exhibited acid-triggered endocytosis and cytotoxicity in cellulo and, higher tumor accumulation and anticancer activity over rHDL/GA NP in vivo after systemic injection. The tumor selectivity and treatment benefit achieved by this simple modification makes it a good candidate to turn conventional drug delivery nanocarriers into tumor-targeted ones.

The third option is to convert the CPP into a charge-reversal peptide. This strategy was applied to TAT for doxorubicin delivery [71]. TAT was converted into an acidosis-sensitive CPP, by amidization of the lysine residues (amidized TAT, aTAT) imparting them a negative charge at neutral $\mathrm{pH}$. They took advantage of the enhanced degradation of amide groups at $\mathrm{pH} 6.0$ over $\mathrm{pH} 7.4$ to induce an acidosis-triggered recovery of lysine positive charge to trigger TAT-mediated endocytosis in the acidic tumor environment.

aTAT-conjugated doxorubicin-loaded micelles displayed decreased blood clearance and 4-fold higher doxorubicin accumulation in tumor tissues over conventional TAT-modified micelles, demonstrating acid-triggered endocytosis in tumors after systemic administration of a nanocarrier with acid $\mathrm{pH}$-dependent charge reversal.

A further refinement in using amides for tumor targeting has been described by Han and coworkers with, amidization of both the copolymer and the CPP leading to stepwise charge-reversal for enhanced doxorubicin nuclear uptake [72].

Their design consists in using a poly-L-Lysine / poly-L-Leucine diblock copolymer where the lysine residues are amidized by 2,3-dimethylmaleicanhydride (PLLeu-PLL(DMA)) and TAT's lysine are amidized by succinyl chloride (TAT(SA)) to obtain PLLeu-PLL(DMA)-TAT(SA), PPDTS micelles. 
PPDTS could self-assemble in $20 \mathrm{~nm}$ spherical micelles capable of high doxorubicin loading (15.6\% by weight). A dramatic induction of cellular uptake by environmental acidity was measured by flow cytometry: whereas only $12 \%$ cells were positive for PPDTS after incubation at $\mathrm{pH} 7.4$, this proportion reached $46 \%$ after incubation at $\mathrm{pH}$ 6.5. Moreover, TAT (SA) intracellular activation led to superior doxorubicin delivery in the nucleus over PPD, resulting in higher cytotoxicity.

\subsection{Redox-Responsive CPP-Modified Nanocarriers}

Redox imbalance is another tumor environment feature that gives cancer cells a proliferation advantage due to the activation of drug resistance and detoxification pathways [73]. The reductive stress of tumors is exemplified by the 2- to 10-fold higher glutathione (GSH) concentration in tumors over normal tissues [73,74]. Accordingly, nanocarriers with reduction-responsive units have been frequently used for tumor-targeted delivery $[74,75]$.

As a proof of concept, Fu et al. designed PTX-loaded liposomes with two successive layers of PEG coating: a reduction-sensitive outer PEG coating made of DSPE-S-S-PEG5000 as scabbard for another DSPE-PEG2000-TAT layer closer to the liposome surface (Cleavable TAT liposomes, C-TAT-LP) [76]. Using 20-fold more DSPE-S-S-PEG5000 over DSPE-PEG2000-TAT they were able to seal TAT activity both in cellulo and in vivo. In cellulo, the cellular uptake of PTX-loaded redox-responsive liposomes increased by 4 -fold after incubation with recombinant GSH. GSH incubation also conditioned the cytotoxicity against cancer cell lines. Intravenous injection of C-TAT-LP followed by recombinant GSH injection in murine melanoma models led to superior distribution to tumors and tumor growth inhibition over liposomes harboring TAT without a stimuli-responsive coating (TAT-LP). Notably, the decreased tumor accumulation of "always on CPP" liposomes could be attributed to their dominant accumulation in the liver, implying a significant contribution of non-specific uptake of TAT-LP to their inferior therapeutic activity.

\section{Nanocarriers Modified with Intracellular Penetrating Peptides}

Even after blood circulation, having reached the targeted organ and CPP-mediated crossing of diseased cell membrane, nanocarriers still require to deliver the cargo to its precise subcellular site of action such as the nucleus for pDNA and genotoxic agents or, mitochondria for several anticancer drugs [77]. However, the dense cytoskeleton, the abundance of organelles and the rapid degradation of nucleic acids inside cells are significant obstacles to their intracellular movement $[78,79]$.

The same way that CPPs were discovered from the study of virus cellular entry (with HIV-1 TAT in 1988 [80], motifs facilitating intracellular trafficking to organelles -intracellular penetrating peptides (IPPs)- by mimicry of viral mechanisms were also discovered [81-84].

Elimination of infected cells by induction of mitochondrial apoptosis pathways after intracellular recognition of viral components is one of the mechanisms to limit virus spread [81]. Coevolution of viruses with mammalian cells led them to develop anti-apoptotic viral proteins with mitochondrial targeting sequences (MTS) to maintain host cells alive. Most of these MTS are a mix of hydrophobic and positively charged residues to interact with the negative mitochondrial membrane potential [81,85]. One of the most advanced mitochondria-targeting nanocarrier is the dual function MITO-Porter system of Pr. Harashima's group [86]. These liposomes display the positively charged octaarginine (R8) peptide as both CPP and MTS to promote interaction with cellular and outer mitochondrial membranes. MITO-Porter is a multistage nanocarrier where an outer layer of R8 serves as CPP to enter cells by micropinocytosis which leads to their accumulation inside endosomes. Inside the endosomes, the outer envelope of MITO-Porter which is made of endosomal fusogenic lipids allows endosomal escape. Then, another series of R8 serve as MTS to allow intra-mitochondrial cargo delivery [87].

In one of MITO-Porter's applications, the cargo is the anti-oxidant Coenzyme Q10 (CoQ10) and, systemic administration of MITO-Porter / CoQ10 prevented ischemia / reperfusion injury in a murine model [88]. 
Another example of improved intracellular cargo routing is the work of Pigeon et al. who favored migration of exogenous DNA towards the nucleus by an adenovirus-inspired mechanism [84]. They exploited the interaction of the adenovirus protein E3-14.7K with dynein light chain (dynein light chain Tctex type 1, DYNLT1) via FIP-1 (Fourteen.7K interacting protein), an interaction that brings it closer to the nuclear envelope by microtubule hitchhiking [89]. As the coupling of a $14.7 \mathrm{KDa}$ protein to DNA could have been too challenging, they first determined the minimal E3 14.7K sequence sufficient for interaction with FIP-1 and microtubules (peptide P79-98). Next, the coupling of this peptide to pDNA using biotin/streptavidin chemistry increased its interaction with FIP-1 and directional pDNA transport to the nucleus along microtubules, resulting in enhanced gene expression of pDNA with the P79-98 peptide.

Rather than focusing on how viruses traffic inside cells, Sullivan's group studied nuclear reorganization after mitosis to identify motifs allowing enhanced exogenous DNA distribution to the nucleus for better transgene expression [90-92]. Their hypothesis was, that because successful transfection by polyplexes and lipoplexes is correlated with the nuclear envelope breakdown during mitosis [93-95], hijacking of nucleus reorganization pathways after mitosis would increase nuclear delivery of exogenous DNA in dividing cells.

They exploited histone sorting pathways as a strategy of epigenetic enhancement of polyethylenimine (PEI)-mediated DNA transfection efficiency. This form of nuclear targeting has three requirements: the hijacking modification should not prevent cellular uptake, promote endosomal escape and nuclear delivery. Integration of these necessities in a single nanocarrier was achieved using a combination of PEI for DNA complexation, endosomal escape and intracellular delivery; hijacking of histone $\mathrm{H} 3$ methyltransferase (H3MT) retrograde transport pathway to direct DNA to perinuclear regions and; histone H3 N-terminal nuclear localization sequence (NLS) for nuclear delivery [96,97].

Particularly, they relied on the dual subcellular localization of the DPY-30 subunit of H3MT [98]. DPY-30 has both a nuclear pool and a perinuclear trans-Golgi network (TGN) pool and, serves as an endosome to TGN retrograde transporter for cargoes such as the cation-independent mannose 6-phosphate receptor (CIMPR) [98]. H3 peptide conjugation favorably altered the intracellular trafficking of the polyplexes in several ways. First, H3 targeting enhanced polyplexes endocytosis via caveolae rather than clathrin-mediated endocytosis, a critical feature since previous studies identified caveolae uptake as the most significant contributor for PEI gene delivery [99]. Second, the H3 peptide increased the perinuclear distribution of DNA. Third, the perinuclear accumulation of H3-targeted PEI polyplexes favored nuclear incorporation of DNA during nuclear envelope reassembly after mitosis. In addition to routing DNA to the nucleus, conjugation of $\mathrm{H} 3$ peptide facilitated gene expression compared to unconjugated PEI polyplexes [90].

Altogether, their strategy opens a new avenue of bioinspired mechanisms to negotiate endosomal escape and nuclear delivery barriers for gene therapy.

\section{Clinical Trials}

Several CPP-based strategies are under clinical trials (Table 2) (reviewed in [21,22,32]). AM-111 (Auris Medical) is a conjugate of the Janus Kinase inhibitor brimapitide and TAT CPP [100]. It is administered as an otic gel for intratympanic use to treat acute hearing loss. A Phase 2 trial of AM-111 demonstrated improved hearing threshold, speech discrimination and complete tinnitus remission compared with placebo in patients who suffered from acute noise trauma. These results led to orphan drug designation of AM-111 by both the US Food \& Drug Administration and the European Medicines Agency for the treatment of acute sensorineural hearing loss. AM-111 was also granted fast track designation and entered a Phase 3 trial.

Another CPP-based strategy in clinical trials is the Kisima platform developed by AMAL therapeutics. This platform combines the Z13 CPP (KRYKNRVASRKSRAKFKQLLQHYREVAAAKSSENDRLRLLLK) derived from the ZEBRA trans-activator of Epstein-Barr virus [101], a multiantigen domain (Mad) consisting of portions of cancer antigens and an adjuvant peptide from the N-terminus of 
Annexin 2 (Anexa, STVHEILCKLSLEGDHSTPPSAYGSVKPYTNFDAE) [102]. This platform induced antigen-specific immune responses in mice and non-human primates. AMAL will conduct an international Phase Ib clinical study, referred to as KISIMA-01, to evaluate the combination of its lead candidate, ATP128,with Boehringer Ingelheim's anti-PD1 compound, BI754091, in Microsatellite Stable (MSS) patients with stage IV colorectal cancer (NCT04046445).

Table 2. Examples of CPP-based strategies under clinical development.

\begin{tabular}{|c|c|c|c|c|c|}
\hline Company & Compound & CPP-Cargo & Condition & Status & Ref \\
\hline Auris Medicals & AM-111 & TAT-brimapitide & $\begin{array}{c}\text { Acute innear } \\
\text { ear hearing loss }\end{array}$ & Phase 3 & [100] \\
\hline $\begin{array}{c}\text { AMAL } \\
\text { Therapeutics }\end{array}$ & KISIMA & Z13-Mad-Anexa & Cancer & Phase 1 & [102] \\
\hline $\begin{array}{c}\text { Revance } \\
\text { Therapeutics }\end{array}$ & RT002 & $\begin{array}{c}\text { TransMTS1-botulinum } \\
\text { toxin A }\end{array}$ & Glabellar lines & Phase 2 & [103] \\
\hline $\begin{array}{c}\text { Avelas } \\
\text { Biosciences }\end{array}$ & AVB-620 & $\begin{array}{l}\text { R9-Cy5/Cy7 FRET } \\
\text { pair }\end{array}$ & $\begin{array}{c}\text { Intraoperative } \\
\text { tumor } \\
\text { detection }\end{array}$ & Phase $2 / 3$ & [105] \\
\hline Amgen & KAI-9803 & TAT- $\delta$ PKC inhibitor & $\begin{array}{l}\text { Myocardial } \\
\text { infarction }\end{array}$ & & [104] \\
\hline
\end{tabular}

Revance Therapeutics developed RT-002 for local treatment of lateral canthal lines [103]. It is a conjugate between botulinum toxin A neurotoxin and a macromolecule transport system derived from $\mathrm{TAT}_{49-57}$ domain. It is in clinical trials for the treatment of glabellar lines and cervical dystonia (NCT02303002).

Amgen developed KAI-9803, a delta protein kinase C ( $\delta \mathrm{PKC}$ ) inhibitor derived from the $\delta \mathrm{V} 1-1$ domain of $\delta$ PKC $[27,104]$. This inhibitor is coupled to TAT $_{47-57}$. This conjugate limited total infarct size in a Phase 2 trial in acute myocardial infarction (NCT00785954).

The high specificity of MMP-sensitive ACPP fluorescent probe has been applied for intraoperative tumor detection during mastectomy and sentinel lymph node dissection [105]. Intravenous injection of AVB-620 2-20 h before surgery allowed tumor specific fluorescence detection and improved resection margins during a Phase 1 trial. This compound is now entering a Phase $2 / 3$ trial to evaluate the accuracy of AVB-620 imaging data to distinguish between malignant and non-malignant tissues (NCT03113825).

\section{Conclusions}

Although promising results in drug delivery have been achieved with conventional CPPs, their lack of targeting specificity limits their clinical translation $[9,11,14]$. Taming the power of CPPs by a stimuli-sensitive scabbard to turn them from blind cell membrane busters into spotters allowing cargo delivery only to the targeted diseased cell $[8,14,42,54]$.

Here I described stimuli-triggered CPPS as a powerful tool for tissue factor-activated endocytosis of nanocarriers. Sensitivity to pathophysiological traits (acidosis, redox imbalance, overexpression of proteases) and physical stimuli (light) allows fine control of CPPs activation for improved selectivity and therapeutic index.

However, several outstanding questions need to be addressed to improve the penetrance of stimuli-responsive CPPs in the targeted drug delivery field.

First, the same way that advancement of conventional CPPs-mediated drug delivery benefited from detailed mechanistic studies, stimuli-specific investigations are required to uncover the full potential of stimuli-responsive CPP-modified nanocarriers [14,16,39,54]. To address this aspect, standard assessment methods may need to be developed to clarify the contradicting mechanistic results reported for same CPPs by different authors $[12,106]$. 
Second, biodistribution of stimuli-responsive CPPs in patients affected not only by a primary disease but, also by secondary pathologies such as AIDS-related immune-depression or arthritis-related chronic inflammation in elderly patients, should be considered to define their targeting potential [107].

Third, stimuli-responsive CPP-modified nanocarriers may face the same complexity and cost-versus-benefits limitations of ligand-targeted nanomedicines and, these should be evaluated as they could delay their clinical translation because of costs, production and intellectual property problems [108,109].

Finally, after stimuli-triggered CPP-facilitated entry into the targetedcell, the carried drug still requires to reach its intracellular target to exert its pharmacological activity [7]. This is where IPPs enter in action to route the drug to particular subcellular compartments for improved therapeutic activity at decreased dosage. The potential of scaling-up may be limited by the increased complexity and number of domains of stimuli-sensitive CPPs, facing the same unfavorable cost versus benefit of targeted nanoparticles $[108,110]$. However, this field will benefit from the ligand-targeted nanomedecines in clinical trials [111].

The ultimate goal of CPP-mediated cargo delivery could be an integrative strategy involving both stimuli-sensitive CPPs for tissue-specific endocytosis and IPPs to route the pharmacological agents to their site of action inside the cell. Ultimately, the future of stimuli-responsive CPPs will benefit from the feedback of CPP-conjugated drugs in clinical trials to synthetize a library of targeted nanocarriers with tropism towards most human diseases.

Funding: This research received no external funding.

Conflicts of Interest: The author declares no conflict of interest.

\section{References}

1. Barenholz, Y.C. Doxil-The first FDA-approved nano-drug: Lessons learned. J. Control. Release 2012, 160, 117-134. [CrossRef] [PubMed]

2. Davis, M.E.; Chen, Z.; Shin, D.M. Nanoparticle therapeutics: An emerging treatment modality for cancer. Nat. Rev. Drug Discov. 2008, 7, 771-782. [CrossRef] [PubMed]

3. Hrkach, J.; Von Hoff, D.; Mukkaram Ali, M.; Andrianova, E.; Auer, J.; Campbell, T.; De Witt, D.; Figa, M.; Figueiredo, M.; Horhota, A.; et al. Preclinical development and clinical translation of a PSMA-targeted docetaxel nanoparticle with a differentiated pharmacological profile. Sci. Transl. Med. 2012, 4, 128ra139. [CrossRef] [PubMed]

4. Mahato, R.I.; Narang, A.S. Pharmaceutical Dosage Forms and Drug Delivery; CRC Press: Boca Raton, FL, USA, 2011.

5. Micheel, C.; Patlak, M. Nanotechnology and Oncology: Workshop Summary; National Academies Press: Washington, DC, USA, 2011.

6. Torchilin, V. Handbook of Materials for Nanomedicine; Informa UK Limited: London, UK, 2010; Volume 1.

7. Jhaveri, A.; Torchilin, V. Intracellular delivery of nanocarriers and targeting to subcellular organelles. Expert Opin. Drug Deliv. 2016, 13, 49-70. [CrossRef]

8. Koren, E.; Torchilin, V.P. Cell-penetrating peptides: Breaking through to the other side. Trends Mol. Med. 2012, 18, 385-393. [CrossRef]

9. Torchilin, V.P. Cell penetrating peptide-modified pharmaceutical nanocarriers for intracellular drug and gene delivery. Pept. Sci. 2008, 90, 604-610. [CrossRef]

10. Elliott, G.; O'Hare, P. Intercellular Trafficking and Protein Delivery by a Herpesvirus Structural Protein. Cell 1997, 88, 223-233. [CrossRef]

11. Zhang, Q.; Gao, H.; He, Q. Taming Cell Penetrating Peptides: Never Too Old To Teach Old Dogs New Tricks. Mol. Pharm. 2015, 12, 3105-3118. [CrossRef]

12. Kauffman, W.B.; Fuselier, T.; He, J.; Wimley, W.C. Mechanism Matters: A Taxonomy of Cell Penetrating Peptides. Trends Biochem. Sci. 2015, 40, 749-764. [CrossRef] 
13. Parodi, A.; Corbo, C.; Cevenini, A.; Molinaro, R.; Palomba, R.; Pandolfi, L.; Agostini, M.; Salvatore, F.; Tasciotti, E. Enabling cytoplasmic delivery and organelle targeting by surface modification of nanocarriers. Nanomedicine 2015, 10, 1923-1940. [CrossRef]

14. Shi, N.Q.; Qi, X.R.; Xiang, B.; Zhang, Y. A survey on “Trojan Horse” peptides: Opportunities, issues and controlled entry to "Troy". J. Control. Release 2014, 194, 53-70. [CrossRef] [PubMed]

15. Perche, F.; Biswas, S.; Torchilin, V.P. Stimuli-Sensitive Polymeric Nanomedicines for Cancer Imaging and Therapy. In Handbook of Polymers for Pharmaceutical Technologies; Wiley: Hoboken, NJ, USA, 2015; Volume 2, pp. 311-344.

16. Li, H.; Tsui, T.Y.; Ma, W. Intracellular Delivery of Molecular Cargo Using Cell-Penetrating Peptides and the Combination Strategies. Int. J. Mol. Sci. 2015, 16, 19518-19536. [CrossRef] [PubMed]

17. Zahid, M.; Robbins, P.D. Cell-Type Specific Penetrating Peptides: Therapeutic Promises and Challenges. Molecules 2015, 20, 13055-13070. [CrossRef] [PubMed]

18. Sawant, R.; Torchilin, V. Intracellular transduction using cell-penetrating peptides. Mol. Biosyst. 2010, 6, 628-640. [CrossRef]

19. Zhu, L.; Wang, T.; Perche, F.; Taigind, A.; Torchilin, V.P. Enhanced anticancer activity of nanopreparation containing an MMP2-sensitive PEG-drug conjugate and cell-penetrating moiety. Proc. Natl. Acad. Sci. USA 2013, 110, 17047-17052. [CrossRef]

20. Lundberg, M.; Wikström, S.; Johansson, M. Cell surface adherence and endocytosis of protein transduction domains. Mol. Ther. 2003, 8, 143-150. [CrossRef]

21. Tripathi, P.P.; Arami, H.; Banga, I.; Gupta, J.; Gandhi, S. Cell penetrating peptides in preclinical and clinical cancer diagnosis and therapy. Oncotarget 2018, 9, 37252-37267. [CrossRef]

22. Guidotti, G.; Brambilla, L.; Rossi, D. Cell-Penetrating Peptides: From Basic Research to Clinics. Trends Pharmacol. Sci. 2017, 38, 406-424. [CrossRef]

23. Lecher, J.C.; Nowak, S.J.; McMurry, J.L. Breaking in and busting out: Cell-penetrating peptides and the endosomal escape problem. Biomol. Concepts 2017, 8, 131-141. [CrossRef]

24. Wadia, J.S.; Stan, R.V.; Dowdy, S.F. Transducible TAT-HA fusogenic peptide enhances escape of TAT-fusion proteins after lipid raft macropinocytosis. Nat. Med. 2004, 10, 310-315. [CrossRef]

25. Vasconcelos, L.; Pärn, K.; Langel, Ü. Therapeutic potential of cell-penetrating peptides. Ther. Deliv. 2013, 4, 573-591. [CrossRef] [PubMed]

26. Lönn, P.; Kacsinta, A.D.; Cui, X.-S.; Hamil, A.S.; Kaulich, M.; Gogoi, K.; Dowdy, S.F. Enhancing Endosomal Escape for Intracellular Delivery of Macromolecular Biologic Therapeutics. Sci. Rep. 2016, 6, 32301.

27. Miyaji, Y.; Walter, S.; Chen, L.; Kurihara, A.; Ishizuka, T.; Saito, M.; Kawai, K.; Okazaki, O. Distribution of KAI-9803, a Novel $\delta$-Protein Kinase C Inhibitor, after Intravenous Administration to Rats. Drug Metab. Dispos. 2011, 39, 1946-1953. [CrossRef] [PubMed]

28. Lo, S.L.; Wang, S. An endosomolytic Tat peptide produced by incorporation of histidine and cysteine residues as a nonviral vector for DNA transfection. Biomaterials 2008, 29, 2408-2414. [CrossRef]

29. Khalil, I.A.; Harashima, H. An efficient PEGylated gene delivery system with improved targeting: Synergism between octaarginine and a fusogenic peptide. Int. J. Pharm. 2018, 538, 179-187. [CrossRef]

30. Liou, J.S.; Liu, B.R.; Martin, A.L.; Huang, Y.W.; Chiang, H.J.; Lee, H.J. Protein transduction in human cells is enhanced by cell-penetrating peptides fused with an endosomolytic HA2 sequence. Peptides 2012, 37, 273-284. [CrossRef]

31. Gautam, A.; Singh, H.; Tyagi, A.; Chaudhary, K.; Kumar, R.; Kapoor, P.; Raghava, G.P.S. CPPsite: A curated database of cell penetrating peptides. Database 2012, 2012, bas015. [CrossRef]

32. Habault, J.; Poyet, J.-L. Recent Advances in Cell Penetrating Peptide-Based Anticancer Therapies. Molecules 2019, 24, 927. [CrossRef]

33. Zorko, M.; Langel, Ü. Cell-penetrating peptides: Mechanism and kinetics of cargo delivery. Adv. Drug Deliv. Rev. 2005, 57, 529-545. [CrossRef]

34. Langel, Ü. Cell-Penetrating Peptides: Methods and Protocols. In Methods in Molecular Biology; Humana Press: Passaic, NJ, USA, 2011; Volume 683.

35. Fu, A.; Wang, Y.; Zhan, L.; Zhou, R. Targeted Delivery of Proteins into the Central Nervous System Mediated by Rabies Virus Glycoprotein-Derived Peptide. Pharm. Res. 2012, 29, 1562-1569. [CrossRef] 
36. Kumar, P.; Wu, H.; McBride, J.L.; Jung, K.-E.; Kim, M.H.; Davidson, B.L.; Lee, S.K.; Shankar, P.; Manjunath, N. Transvascular delivery of small interfering RNA to the central nervous system. Nature 2007, 448, $39-43$. [CrossRef] [PubMed]

37. Khafagy, E.S.; Morishita, M. Oral biodrug delivery using cell-penetrating peptide. Adv. Drug Deliv. Rev. 2012, 64, 531-539. [CrossRef] [PubMed]

38. Nichols, J.W.; Bae, Y.H. Nanotechnology for Cancer Treatment: Possibilities and Limitations. In Cancer Targeted Drug Delivery; Springer: Berlin/Heidelberg, Germany, 2013; pp. 37-56.

39. El-Andaloussi, S.; Järver, P.; Johansson, H.J.; Langel, Ü. Cargo-dependent cytotoxicity and delivery efficacy of cell-penetrating peptides: A comparative study. Biochem. J. 2007, 407, 285-292. [CrossRef]

40. Zhang, W.; Song, J.; Zhang, B.; Liu, L.; Wang, K.; Wang, R. Design of Acid-Activated Cell Penetrating Peptide for Delivery of Active Molecules into Cancer Cells. Bioconjug. Chem. 2011, 22, 1410-1415. [CrossRef] [PubMed]

41. Huang, S.; Shao, K.; Kuang, Y.; Liu, Y.; Li, J.; An, S.; Guo, Y.; Ma, H.; He, X.; Jiang, C. Tumor targeting and microenvironment-responsive nanoparticles for gene delivery. Biomaterials 2013, 34, 5294-5302. [CrossRef]

42. Aguilera, T.A.; Olson, E.S.; Timmers, M.M.; Jiang, T.; Tsien, R.Y. Systemic in vivo distribution of activatable cell penetrating peptides is superior to that of cell penetrating peptides. Integr. Biol. 2009, 1, 371-381. [CrossRef]

43. Lee, H.J.; Pardridge, W.M. Pharmacokinetics and Delivery of Tat and Tat-Protein Conjugates to Tissues in Vivo. Bioconjug. Chem. 2001, 12, 995-999. [CrossRef]

44. Zhu, L.; Torchilin, V.P. Stimulus-responsive nanopreparations for tumor targeting. Integr. Biol. 2013, 5, 96-107. [CrossRef]

45. Perche, F.; Torchilin, V.P. Recent Trends in Multifunctional Liposomal Nanocarriers for Enhanced Tumor Targeting. J. Drug Deliv. 2013, 2013, 1-32. [CrossRef]

46. Roberts, M.; Bentley, M.; Harris, J. Chemistry for peptide and protein PEGylation. Adv. Drug Deliv. Rev. 2012, 64, 116-127. [CrossRef]

47. Veronese, F.M.; Pasut, G. PEGylation, successful approach to drug delivery. Drug Discov. Today 2005, 10, 1451-1458. [CrossRef]

48. Fomina, N.; Sankaranarayanan, J.; Almutairi, A. Photochemical mechanisms of light-triggered release from nanocarriers. Adv. Drug Deliv. Rev. 2012, 64, 1005-1020. [CrossRef] [PubMed]

49. Gohy, J.F.; Zhao, Y. Photo-responsive block copolymer micelles: Design and behavior. Chem. Soc. Rev. 2013, 42, 7117-7128. [CrossRef] [PubMed]

50. Yang, Y.; Yang, Y.; Xie, X.; Cai, X.; Mei, X. Preparation and characterization of photo-responsive cell-penetrating peptide-mediated nanostructured lipid carrier. J. Drug Target. 2014, 22, 891-900. [CrossRef] [PubMed]

51. Kim, K.; Park, H.; Lim, K.-M. Phototoxicity: Its Mechanism and Animal Alternative Test Methods. Toxicol. Res. 2015, 31, 97-104. [CrossRef]

52. Yang, Y.; Xie, X.; Yang, Y.; Zhang, H.; Mei, X. Photo-Responsive and NGR-Mediated Multifunctional Nanostructured Lipid Carrier for Tumor-Specific Therapy. J. Pharm. Sci. 2015, 104, 1328-1339. [CrossRef]

53. Hua, H.; Li, M.; Luo, T.; Yin, Y.; Jiang, Y. Matrix metalloproteinases in tumorigenesis: An evolving paradigm. Cell. Mol. Life Sci. 2011, 68, 3853-3868. [CrossRef]

54. He, H.; Sun, L.; Ye, J.; Liu, E.; Chen, S.; Liang, Q.; Shin, M.C.; Yang, V.C. Enzyme-triggered, cell penetrating peptide-mediated delivery of anti-tumor agents. J. Control. Release 2016, 240, 67-76. [CrossRef]

55. Roy, R.; Yang, J.; Moses, M.A. Matrix metalloproteinases as novel biomarker s and potential therapeutic targets in human cancer. J. Clin. Oncol. 2009, 27, 5287-5297. [CrossRef]

56. Jiang, T.; Olson, E.S.; Nguyen, Q.T.; Roy, M.; Jennings, P.A.; Tsien, R.Y. Tumor imaging by means of proteolytic activation of cell-penetrating peptides. Proc. Natl. Acad. Sci. USA 2004, 101, 17867-17872. [CrossRef]

57. Savariar, E.N.; Felsen, C.N.; Nashi, N.; Jiang, T.; Ellies, L.G.; Steinbach, P.; Tsien, R.Y.; Nguyen, Q.T. Real-time in vivo molecular detection of primary tumors and metastases with ratiometric activatable cell-penetrating peptides. Cancer Res. 2013, 73, 855-864. [CrossRef] [PubMed]

58. Zhang, B.; Zhang, Y.; Liao, Z.; Jiang, T.; Zhao, J.; Tuo, Y.; She, X.; Shen, S.; Chen, J.; Zhang, Q.; et al. UPA-sensitive ACPP-conjugated nanoparticles for multi-targeting therapy of brain glioma. Biomaterials 2015, 36, 98-109. [CrossRef] [PubMed] 
59. Xiang, B.; Dong, D.W.; Shi, N.Q.; Gao, W.; Yang, Z.Z.; Cui, Y.; Cao, D.Y.; Qi, X.R. PSA-responsive and PSMA-mediated multifunctional liposomes for targeted therapy of prostate cancer. Biomaterials 2013, 34, 6976-6991. [CrossRef] [PubMed]

60. Lee, E.S.; Gao, Z.; Bae, Y.H. Recent progress in tumor pH targeting nanotechnology. J. Control. Release 2008, 132, 164-170. [CrossRef]

61. Liu, J.; Huang, Y.; Kumar, A.; Tan, A.; Jin, S.; Mozhi, A.; Liang, X.J. pH-Sensitive nano-systems for drug delivery in cancer therapy. Biotechnol. Adv. 2014, 32, 693-710. [CrossRef]

62. Van Sluis, R.; Bhujwalla, Z.M.; Raghunand, N.; Ballesteros, P.; Galons, J.-P.; Gillies, R.J.; Alvarez, J.; Cerdán, S.; Galons, J. In vivo imaging of extracellular pH using1H MRSI. Magn. Reson. Med. 1999, 41, 743-750. [CrossRef]

63. Apte, A.; Koren, E.; Koshkaryev, A.; Torchilin, V.P. Doxorubicin in TAT peptide-modified multifunctional immunoliposomes demonstrates increased activity against both drug-sensitive and drug-resistant ovarian cancer models. Cancer Biol. Ther. 2014, 15, 69-80. [CrossRef]

64. Koren, E.; Apte, A.; Jani, A.; Torchilin, V.P. Multifunctional PEGylated 2C5-immunoliposomes containing $\mathrm{pH}$-sensitive bonds and TAT peptide for enhanced tumor cell internalization and cytotoxicity. J. Control. Release 2012, 160, 264-273. [CrossRef]

65. Song, J.; Kai, M.; Zhang, W.; Zhang, J.; Liu, L.; Zhang, B.; Liu, X.; Wang, R. Cellular uptake of transportan 10 and its analogs in live cells: Selectivity and structure-activity relationship studies. Peptides 2011, 32, 1934-1941. [CrossRef]

66. Zhang, Q.; Tang, J.; Fu, L.; Ran, R.; Liu, Y.; Yuan, M.; He, Q. A pH-responsive $\alpha$-helical cell penetrating peptide-mediated liposomal delivery system. Biomaterials 2013, 34, 7980-7993. [CrossRef]

67. Shi, K.; Li, J.; Cao, Z.; Yang, P.; Qiu, Y.; Yang, B.; Wang, Y.; Long, Y.; Liu, Y.; Zhang, Q. A pH-responsive cell-penetrating peptide-modified liposomes with active recognizing of integrin $\alpha \mathrm{v} \beta 3$ for the treatment of melanoma. J. Control. Release 2015, 217, 138-150. [CrossRef] [PubMed]

68. Shi, K.; Long, Y.; Xu, C.; Wang, Y.; Qiu, Y.; Yu, Q.; Liu, Y.; Zhang, Q.; Gao, H.; Zhang, Z. Liposomes Combined an Integrin $\alpha v \beta 3$-Specific Vector with $\mathrm{pH}$-Responsible Cell-Penetrating Property for Highly Effective Antiglioma Therapy through the Blood-Brain Barrier. ACS Appl. Mater. Interfaces 2015, 7, 21442-21454. [CrossRef] [PubMed]

69. Ding, Y.; Wang, Y.; Opoku-Damoah, Y.; Wang, C.; Shen, L.; Yin, L.; Zhou, J. Dual-functional bio-derived nanoparticulates for apoptotic antitumor therapy. Biomaterials 2015, 72, 90-103. [CrossRef] [PubMed]

70. Jiang, T.; Zhang, Z.; Zhang, Y.; Lv, H.; Zhou, J.; Li, C.; Hou, L.; Zhang, Q. Dual-functional liposomes based on $\mathrm{pH}$-responsive cell-penetrating peptide and hyaluronic acid for tumor-targeted anticancer drug delivery. Biomaterials 2012, 33, 9246-9258. [CrossRef] [PubMed]

71. Jin, E.; Zhang, B.; Sun, X.; Zhou, Z.; Ma, X.; Sun, Q.; Tang, J.; Shen, Y.; Van Kirk, E.; Murdoch, W.J.; et al. Acid-Active Cell-Penetrating Peptides for in Vivo Tumor-Targeted Drug Delivery. J. Am. Chem. Soc. 2013, 135, 933-940. [CrossRef] [PubMed]

72. Han, S.S.; Li, Z.Y.; Zhu, J.Y.; Han, K.; Zeng, Z.Y.; Hong, W.; Li, W.X.; Jia, H.Z.; Liu, Y.; Zhuo, R.X.; et al. Dual-pH Sensitive Charge-Reversal Polypeptide Micelles for Tumor-Triggered Targeting Uptake and Nuclear Drug Delivery. Small 2015, 11, 2543-2554. [CrossRef] [PubMed]

73. Jorgenson, T.C.; Zhong, W.; Oberley, T.D. Redox imbalance and biochemical changes in cancer. Cancer Res. 2013, 73, 6118-6123. [CrossRef]

74. Ge, Z.; Liu, S. Functional block copolymer assemblies responsive to tumor and intracellular microenvironments for site-specific drug delivery and enhanced imaging performance. Chem. Soc. Rev. 2013, 42, 7289-7325. [CrossRef]

75. Li, Y.; Xiao, K.; Zhu, W.; Deng, W.; Lam, K.S. Stimuli-responsive cross-linked micelles for on-demand drug delivery against cancers. Adv. Drug Deliv. Rev. 2014, 66, 58-73. [CrossRef]

76. Fu, H.; Shi, K.; Hu, G.; Yang, Y.; Kuang, Q.; Lu, L.; Zhang, L.; Chen, W.; Dong, M.; Chen, Y.; et al. Tumor-Targeted Paclitaxel Delivery and Enhanced Penetration Using TAT-Decorated Liposomes Comprising Redox-Responsive Poly(Ethylene Glycol). J. Pharm. Sci. 2015, 104, 1160-1173. [CrossRef]

77. Rajendran, L.; Knölker, H.-J.; Simons, K. Subcellular targeting strategies for drug design and delivery. Nat. Rev. Drug Discov. 2010, 9, 29-42. [CrossRef] [PubMed]

78. Lechardeur, D.; Lukacs, G. Intracellular Barriers to Non-Viral Gene Transfer. Curr. Gene Ther. 2002, 2, $183-194$. [CrossRef] [PubMed] 
79. Rattan, R.; Bielinska, A.U.; Holl, M.M.B.; Banaszak, M.M. Quantification of cytosolic plasmid DNA degradation using high-throughput sequencing: Implications for gene delivery. J. Gene Med. 2014, 16, 75-83. [CrossRef] [PubMed]

80. Frankel, A.D.; Pabo, C.O. Cellular uptake of the tat protein from human immunodeficiency virus. Cell 1988, 55, 1189-1193. [CrossRef]

81. Boya, P.; Pauleau, A.-L.; Poncet, D.; Gonzalez-Polo, R.-A.; Zamzami, N.; Kroemer, G. Viral proteins targeting mitochondria: Controlling cell death. Biochim. Biophys. Acta BBA Bioenerg. 2004, 1659, 178-189. [CrossRef]

82. Carlisle, R.C.; Bettinger, T.; Ogris, M.; Hale, S.; Mautner, V.; Seymour, L.W. Adenovirus Hexon Protein Enhances Nuclear Delivery and Increases Transgene Expression of Polyethylenimine/Plasmid DNA Vectors. Mol. Ther. 2001, 4, 473-483. [CrossRef]

83. Moseley, G.W.; Roth, D.M.; DeJesus, M.A.; Leyton, D.L.; Filmer, R.P.; Pouton, C.W.; Jans, D.A. Dynein Light Chain Association Sequences Can Facilitate Nuclear Protein Import. Mol. Boil. Cell 2007, 18, 3204-3213. [CrossRef]

84. Pigeon, L.; Gonçalves, C.; Gosset, D.; Pichon, C.; Midoux, P. An E3-14.7K Peptide that Promotes Microtubules-Mediated Transport of Plasmid DNA Increases Polyplexes Transfection Efficiency. Small 2013, 9, 3845-3851. [CrossRef]

85. Lemasters, J.J.; Ramshesh, V.K. Imaging of Mitochondrial Polarization and Depolarization with Cationic Fluorophores. Methods Cell Biol. 2007, 80, 283-295.

86. Yamada, Y.; Akita, H.; Kamiya, H.; Kogure, K.; Yamamoto, T.; Shinohara, Y.; Yamashita, K.; Kobayashi, H.; Kikuchi, H.; Harashima, H. MITO-Porter: A liposome-based carrier system for delivery of macromolecules into mitochondria via membrane fusion. Biochim. Biophys. Acta BBA Biomembr. 2008, 1778, 423-432. [CrossRef]

87. Yamada, Y.; Furukawa, R.; Yasuzaki, Y.; Harashima, H. Dual Function MITO-Porter, a Nano Carrier Integrating Both Efficient Cytoplasmic Delivery and Mitochondrial Macromolecule Delivery. Mol. Ther. 2011, 19, 1449-1456. [CrossRef] [PubMed]

88. Yamada, Y.; Nakamura, K.; Abe, J.; Hyodo, M.; Haga, S.; Ozaki, M.; Harashima, H. Mitochondrial delivery of Coenzyme Q10 via systemic administration using a MITO-Porter prevents ischemia/reperfusion injury in the mouse liver. J. Control. Release 2015, 213, 86-95. [CrossRef] [PubMed]

89. Kelkar, S.A.; Pfister, K.K.; Crystal, R.G.; Leopold, P.L. Cytoplasmic Dynein Mediates Adenovirus Binding to Microtubules. J. Virol. 2004, 78, 10122-10132. [CrossRef] [PubMed]

90. Larsen, J.D.; Reilly, M.J.; Sullivan, M.O. Using the Epigenetic Code to Promote the Unpackaging and Transcriptional Activation of DNA Polyplexes for Gene Delivery. Mol. Pharm. 2012, 9, 1041-1051. [CrossRef]

91. Reilly, M.J.; Larsen, J.D.; Sullivan, M.O. Histone H3 Tail Peptides and Poly (ethylenimine) Have Synergistic Effects for Gene Delivery. Mol. Pharm. 2012, 9, 1031-1040. [CrossRef]

92. Ross, N.L.; Munsell, E.V.; Sabanayagam, C.; O Sullivan, M. Histone-targeted Polyplexes Avoid Endosomal Escape and Enter the Nucleus during Postmitotic Redistribution of ER Membranes. Mol. Ther. Nucleic Acids 2015, 4, e226. [CrossRef]

93. Brunner, S.; Sauer, T.; Carotta, S.; Cotten, M.; Saltik, M.; Wagner, E. Cell cycle dependence of gene transfer by lipoplex, polyplex and recombinant adenovirus. Gene Ther. 2000, 7, 401-407. [CrossRef]

94. Fasbender, A.; Zabner, J.; Zeiher, B.; Welsh, M. A low rate of cell proliferation and reduced DNA uptake limit cationic lipid-mediated gene transfer to primary cultures of ciliated human airway epithelia. Gene Ther. 1997, 4, 1173-1180. [CrossRef]

95. Rémy-Kristensen, A.; Clamme, J.-P.; Vuilleumier, C.; Kuhry, J.G.; Mély, Y. Role of endocytosis in the transfection of L929 fibroblasts by polyethylenimine/DNA complexes. Biochim. Biophys. Acta BBA Biomembr. 2001, 1514, 21-32. [CrossRef]

96. Boussif, O.; Lezoualc'h, F.; Zanta, M.A.; Mergny, M.D.; Scherman, D.; Demeneix, B.; Behr, J.-P. A versatile vector for gene and oligonucleotide transfer into cells in culture and in vivo: Polyethylenimine. Proc. Natl. Acad. Sci. USA 1995, 92, 7297-7301. [CrossRef]

97. Mosammaparast, N.; Guo, Y.; Shabanowitz, J.; Hunt, D.F.; Pemberton, L.F. Pathways mediating the nuclear import of histones $\mathrm{H} 3$ and $\mathrm{H} 4$ in yeast. J. Biol. Chem. 2002, 277, 862-868. [CrossRef] [PubMed]

98. Xu, Z.; Gong, Q.; Xia, B.; Groves, B.; Zimmermann, M.; Mugler, C.; Mu, D.; Matsumoto, B.; Seaman, M.; $\mathrm{Ma}, \mathrm{D}$. A role of histone $\mathrm{H} 3$ lysine 4 methyltransferase components in endosomal trafficking. J. Cell Biol. 2009, 186, 343-353. [CrossRef] [PubMed] 
99. Gabrielson, N.P.; Pack, D.W. Efficient polyethylenimine-mediated gene delivery proceeds via a caveolar pathway in HeLa cells. J. Control. Release 2009, 136, 54-61. [CrossRef] [PubMed]

100. Suckfuell, M.; Lisowska, G.; Domka, W.; Kabacinska, A.; Morawski, K.; Bodlaj, R.; Klimak, P.; Kostrica, R.; Meyer, T. Efficacy and safety of AM-111 in the treatment of acute sensorineural hearing loss: A double-blind, randomized, placebo-controlled phase II study. Otol. Neurotol. 2014, 35, 1317-1326. [CrossRef]

101. Rothe, R.; Liguori, L.; Villegas-Mendez, A.; Marques, B.; Grunwald, D.; Drouet, E.; Lenormand, J.L. Characterization of the Cell-penetrating Properties of the Epstein-Barr Virus ZEBRA trans-Activator. J. Biol. Chem. 2010, 285, 20224-20233. [CrossRef]

102. Belnoue, E.; Mayol, J.-F.; Carboni, S.; Besson, W.D.B.; Dupuychaffray, E.; Nelde, A.; Stevanovic, S.; Santiago-Raber, M.L.; Walker, P.R.; Derouazi, M. Targeting self and neo-epitopes with a modular self-adjuvanting cancer vaccine. JCI Insight 2019, 5, 127305. [CrossRef]

103. Garcia-Murray, E.; Villasenor, M.L.V.; Acevedo, B.; Luna, S.; Lee, J.; Waugh, J.M.; Hornfeldt, C.S. Safety and efficacy of RT002, an injectable botulinum toxin type A, for treating glabellar lines: Results of a phase 1/2, open-label, sequential dose-escalation study. Dermatol. Surg. 2015, 41, S47-S55. [CrossRef]

104. Bates, E.; Bode, C.; Costa, M.; Gibson, C.M.; Granger, C.; Green, C.; Grimes, K.; Harrington, R.; Huber, K.; Kleiman, N. Intracoronary KAI-9803 as an adjunct to primary percutaneous coronary intervention for acute ST-segment elevation myocardial infarction. Circulation 2008, 117, 886-896.

105. Unkart, J.T.; Wapnir, I.L.; González, J.E.; Harootunian, A.; Wallace, A.M.; Chen, S.L. Intraoperative Tumor Detection Using a Ratiometric Activatable Fluorescent Peptide: A First-in-Human Phase 1 Study. Ann. Surg. Oncol. 2017, 24, 3167-3173. [CrossRef]

106. Schmidt, S.; Adjobo-Hermans, M.J.W.; Wallbrecher, R.; Verdurmen, W.P.R.; Bovee-Geurts, P.H.M.; Van Oostrum, J.; Milletti, F.; Enderle, T.; Brock, R. Detecting Cytosolic Peptide Delivery with the GFP Complementation Assay in the Low Micromolar Range. Angew. Chem. 2015, 127, 15320-15323. [CrossRef]

107. Bae, Y.H.; Mrsny, R.J.; Park, K. Cancer Targeted Drug Delivery: An Elusive Dream; Springer Science \& Business Media: Berlin/Heidelberg, Germany, 2013.

108. Cheng, Z.; Al Zaki, A.; Hui, J.Z.; Muzykantov, V.R.; Tsourkas, A. Multifunctional Nanoparticles: Cost versus benefit of adding targeting and imaging capabilities. Science 2012, 338, 903-910. [CrossRef] [PubMed]

109. Eaton, M.A.; Lévy, L.; Fontaine, O.M. Delivering nanomedicines to patients: A practical guide. Nanomed. Nanotechnol. Biol. Med. 2015, 11, 983-992. [CrossRef] [PubMed]

110. Maeda, H.; Nakamura, H.; Fang, J. The EPR effect for macromolecular drug delivery to solid tumors: Improvement of tumor uptake, lowering of systemic toxicity, and distinct tumor imaging in vivo. Adv. Drug Deliv. Rev. 2013, 65, 71-79. [CrossRef] [PubMed]

111. Mi, P.; Cabral, H.; Kataoka, K. Ligand-Installed Nanocarriers toward Precision Therapy. Adv. Mater. 2019, 1902604. [CrossRef] [PubMed]

(C) 2019 by the author. Licensee MDPI, Basel, Switzerland. This article is an open access article distributed under the terms and conditions of the Creative Commons Attribution (CC BY) license (http://creativecommons.org/licenses/by/4.0/). 